\title{
SKEPTISME NASABAH TERHADAP KLAIM SYARIAH DARI PERBANKAN SYARIAH DI INDONESIA
}

\author{
Alex Fahrur Riza \\ UIN Sunan Kalijaga Yogyakarta \\ Email: Alex.fahrurriza7@gmail.com
}

\begin{abstract}
This study aims to examine the factors that affect level of skepticism of Islamic bank customers where researchers try to see the paradigm of thinking and consumer attitude using the perspective of Theory of Reason Action (TRA) from Ajzen and Fishbein (1980). The survey was conducted on 597 Islamic bank customers using a Google form distributed online. All hypotheses proposed in this study are supported. These results show that in the context of Islamic banking in Indonesia, researchers find that the level of skepticism will decrease as customers better understand the information received and evaluate information according to their needs and according to their expectations. Researchers try to contribute both practically and theoretically.First, practically this research provides important information for practitioners that customers still have a skeptical attitude towards sharia claims from Islamic banking. Finally, theoretically this study contributes to the literature by testing the skepticism of Islamic banking customers which is still a research gap in marketing research and consumer behavior in general and the research of sharia banking in particular.
\end{abstract}

Keywords: consumers scepticism, cognitions, emotions, brand experiences, islamic banking

\section{PENDAHULUAN}

Secara global, perbankan syariah berkembang dengan cukup cepat selama tiga dekade terakhir dan sampai saat ini masih menjadi topik perbincangan yang hangat di kalangan industri keuangan di berbagai negara termasuk Indonesia. Hal ini dikarenakan perbankan syariah terbukti mampu bertahan dalam dua periode krisis yang terjadi pada tahun 1997 dan tahun 2008 . Saat krisis tahun 1997 bank syariah mampu bertahan di tengah masa sulit dengan rasio modal diatas 4\% dan meskipun mengalami kerugian operasional hingga Rp.106,983 miliar pada akhir tahun 1998, akan tetapi bank syariah tetap mampu beroperasi tanpa mengikuti program rekapitulasi (www.bankmuamalat.co.id). Krisis tahun 2008 telah membuktikan rapuhnya sistem perbankan konvensional. Krisis ini menunjukkan bahwa ekonomi global tidak cukup hanya mengandalkan negara-negara besar, seperti Amerika dan Eropa untuk menjalankan sistem kebijakan keuangan global (www.bi.go.id).

Kesuksesan bank syariah ini dilandasi oleh beberapa faktor diantaranya seperti berikut. Pertama, perbankan syariah lebih dekat dengan sektor riil karena produk yang ditawarkan senantiasa menggunakan underlying transaction pada sektor riil sehingga dampaknya lebih nyata dalam membangun pertumbuhan ekonomi. Kedua, dalam perbankan syariah tidak terdapat produk-produk yang spekulatif (gharar) sehingga mempunyai daya tahan yang kuat terhadap krisis keuangan global. Ketiga, Profit-loss sharing yang menjadi diferensiasi perbankan syariah membawa manfaat keadilan bagi semua pihak yaitu pemilik dana, pengusaha selaku debitur maupun bank sebagai pengelola dana. 
Jika dibandingkan dengan bank konvensional, usia bank syariah masih di Indonesia tergolong masih belia. Sampai Januari 2017, industri perbankan syariah telah mempunyai jaringan sebanyak 13 Bank Umum Syariah (BUS), 21 Unit Usaha Syariah (UUS) dan 164 BPRS yang tersebar di seluruh nusantara yang menjadikan Indonesia menjadi negara dengan bank syariah terbanyak di dunia. Menurut laporan dari BI menunjukkan bahwa pergerakan Non-Performing Financing (NPF), yaitu rasio yang digunakan untuk mengukur kemampuan manajemen bank syariah dalam mengelola pembiayaan yang bermasalah yang ada dan dapat dipenuhi dengan aktiva produktif yang dimiliki oleh bank syariah cukup stabil dibawah 5\%.

Selain melihat indikator NPF dan kuantitas bank syariah, pesatnya perkembangan industri perbankan syariah karena besarnya potensi segmen pasarnya, dimana penduduk muslim Indonesia yang mencapai 85\% dari total penduduk Indonesia yaitu sekitar 200 juta orang. Perkembangan ini juga didukung pemerintah dengan adanya Komite Nasional Keuangan Syariah (KNKS) yang diketuai langsung oleh Presiden RI. Pemerintah juga membuat Roadmap Perbankan Syariah Indonesia (RPSI) 2015-2019, yaitu rencana pengembangan sektor perbankan syariah Indonesia tahun 2015-2019 yang mengacu pada MPSJKI dan RP2I serta diselaraskan dengan Masterplan Arsitektur Keuangan Syariah Indonesia (AKSI) dari Badan Perencanaan Pembangunan Nasional. RPSI diharapkan dapat menjadi referensi bagi stakeholders perbankan syariah dalam pengembangan industri perbankan syariah sehingga perbankan syariah diharapkan dapat meningkatkan peran dan kontribusinya dalam mendukung perekonomian nasional dan stabilitas sistem keuangan serta peningkatan/ pemerataan kesejahteraan masyarakat.

Di tengah kondisi perekonomian global yang masih dalam tahap pemulihan, kondisi perbankan syariah menunjukkan perkembangan positif. Seluruh indikator kinerja perbankan syariah semakin membaik meliputi pertumbuhan asset, dana pihak ketiga, dan pembiayaan. Akan tetapi ketika kita melihat potensi yang dimiliki perbankan syariah, kenyataannya market share perbankan syariah masih rendah jika dibandingkan dengan industri perbankan konvensional, bahkan tidak pernah melebihi 5\% sampai tahun 2016. Perbankan syariah baru bisa melewati 5\% ketika adanya konversi BPD Aceh menjadi Bank Aceh Syariah pada bulan September 2016, sehingga pada akhir tahun 2016 asset share perbankan syariah naik menjadi 5,33\% dibandingkan tahun sebelumnya sebesar 4,67\%.1

Menurut Calfee dan Ringwold melakukan review selama enam dekade mengenai skeptisme terhadap iklan secara umum, penelitian ini menunjukkan hasil yang konsisten bahwa 70\% konsumen percaya terhadap iklan meskipun ada iklan yangtidak terpercaya, hal ini mengakibatkan orang-orang membeli produk yang tidak mereka butuhkan. Masih ada 30\% konsumen yang tidak percaya terhadap iklan yang disampaikan oleh pemasar. Kepercayaan memainkan peran penting terhadap perilaku konsumen dan kepercayaan pada merek akan mempengaruhi keinginan untuk membeli suatu produk. ${ }^{2}$ Konsumen akankehilangan kepercayaan ketika merek tersebut menyesatkan, tidak bisa dipercaya, dan curang dalam klaimnya. ${ }^{3}$ Peneliti menduga rasa tidak percaya ini juga dimiliki oleh konsumen perbankan syariah, dimana rasa tidak percaya ini muncul karena skeptisme terhadap klaim syariah yang dilakukan oleh perbankan syariah.

Tujuan dari penelitian ini adalah untuk mengetahui tingkat skeptisme nasabah bank syariah di Indonesia mengenai kalim syariah yang dilakukan oleh perbankan syariah. Hal ini penting untuk diteliti karena secara praktis dapat kita ketahui bahwa perbankan syariah

\footnotetext{
1 Otoritas Jasa Keuangan,Booklet Perbankan Indonesia 2017.Departemen Perizinan dan Informasi Perbankan Otoritas Jasa Keuangan, 2017.

2 Jarvenpaa, S.L., Tractinsky, N. dan Vitale, M, Consumer trust in an internet store. Informaation Technology and Management, $1(1), 2000$, pp. 45-71.

3 Calfee, J. E., dan Ringwold, D., The 70\% Majority: Enduring Consumer Belief About Advertising. Journal of Public Policy \& Marketing.13 (2), 1994.
} 
mempunyai potensi yang luar biasa untuk berkembang di Indonesia, akan tetapi sampai sejauh ini baru bisa mencapai market size 5,33\% yang masih sangat jauh jika dibandingkan bank konvensional. Sedangkan secara akademik, berdasarakan penelusuran peneliti mengenai topik skeptisme nasabah perbankan masih belum ada. Hal inilah yang menjadi dasar penelitian perlu dilakukan karena adanya kebutuhan riset untuk sumber kebijakan dalam memajukan industri keuangan dan perbankan syariah di Indonesia.Peneliti menggunakan theory of reason action (TRA) dari Ajzen dan Fishbein (1980) dalam konteks hubungan sikap dan prilaku konsumen perbankan syariah di Indonesia.

\section{TEORI DAN HIPOTESIS}

\section{Perbankan Syariah}

Perbankan Syariah menurut UU No. 21 Tahun 2008 tentang Perbankan Syariah adalah segala sesuatu yang menyangkut tentang Bank Syariah, Unit Usaha Syariah dan Bank Perkreditan Rakyat Syariah, mencakup kelembagaan, kegiatan usaha, serta cara dan proses dalam melakukan kegiatan usahanya. Bank Syariah adalah lembaga keuangan yang dalam aktivitasnya menggunakan dasar hukum syariah, secara prinsip diturunkan dari Al-quran, Hadits, Ijma' dan Qiyas. Fitur utama dari perbankan Syariah adalah menghapus riba dan mempromosikan bagi hasil atau profit-and-loss sharing (PLS). Menurut Capra menegaskan bahwa dalam dunia Islam tidak ada perbedaan sudut pandang mengenai penghapusan riba baik dari Al-Quran maupun Alhadits. Biar bagaimanapun, prinsipPLS ini diturunkan dari prinsip al-ghunm bil-gurm. ${ }^{4}$

\section{Kognisi Pelanggan (Customer Cognition)}

Pembelajaran kognitif konsumen didefinisikan sebagai sebuah proses merasakan stimuli, menghubungkan stimuli dengan kebutuhan, mengevaluasi merek alternatif dan menafsirkan apakah produk tersebut sesuai dengan ekspektasi (Assael, 2004:68). Dalam teori otak tritunggal (Triune Brain Theory) yang dikemukakan oleh Maclean (1990) menyatakan bahwa proses kognisi manusia diproses dalam otak neomamalia yang menjadi pusat dari pemrosesan segala informasi. Kognisi individu erat kaitannya dengan memori, dimana memori itu merupakan proses yang sangat berguna, karena kita tidak bisa mengingat informasi dan kejadian secara lengkap dan akurat. Dalam hal ini, psikologi kognitif membedakan memori manusia menjadi dua: pertama adalah memori jangka pendek (short-term memory) dimana penyimpanan informasi terbatas dan bersifat sementara, dan yang kedua adalah memori jangka panjang (long-term memory) secara esensinya memori akan permanen dan penyimpanan informasinya tidak terbatas. ${ }^{5}$

\section{Emosi Pelanggan (Customer Cognition)}

Emosi merupakan faktor yang penting pada dunia pemasaran saat ini, dimana periklanan dan pemasaran berbeda-beda macamnya dicirikan oleh konten yang digunakan dengan tujuan untuk menempatkan individu ke dalam keadaan emosional yang spesifik (Lindstrom, 2005). Alasan menggunakan emosi dalam pemasaran ini dijelaskan oleh Lindstrom (2005) bahwa emosi dapat membantu pemasar untuk memahami secara lebih baik pada perilaku konsumen dan mengapa konsumen itu mau loyal terhadap sebuah merek tertentu. Menurut Maclean (1990) emosi itu diatur dalam otak paleomamalia atau sistem limbik, yang berhubungan dengan memori dan pengalaman individu. Emosi itu distimulasi oleh panca indera yang mengaktifkan amigdala dan mengirimkan sinyal yang menentukan bagaimana tubuh kita harus bereaksi.

\footnotetext{
4 Chapra, M.U. 2006. The Nature of Riba in Islam. The Journal of Islamic Economics and Finance, 2(1), pp. 7-25.

5 Kotler, P. dan Keller, K.L. 2011. Marketing Management 14th ed. Pearson Education. New Jersey, 2011, h. 163.
} 
Menurut model Mehrabian dan Russel (1974) menunjukkan tiga keadaan emosional dasar manusia yang dikenal sebagai PAD (pleasure, arousal, dominance), yaitu seeprti berikut.

1. Kesenangan (pleasure), yaitu emosi positif yang menyatakan bahwa perasaan dapat dibedakan dari preferensi, kesukaan, dorongan positif dan mendekati ataupun menghindari suatu stimulus lingkungan.

2. Ketergugahan (arousal), yaitu bentuk emosi yang merupakan orientasi aktivitas dan mengukur seberapa terjaga manusia dan seberapa siap untuk bertindak.

3. Dominasi (dominance), yaitu bentuk emosi yang mencerminkan seberapa luas individu merasakan dalam kontrol atau dikuasai lingkungannya.

\section{Pengalaman Merek (Brand Experience)}

Pengalaman merek adalah sensasi, perasaan, kognisi dan respon perilaku yang ditimbulkan oleh stimulus merek terkait yang menjadi bagian dari desain merek dan identitas, kemasan, komunikasi, dan lingkungan. Menurut Brakus, pengalaman konsumen terhadap merek bias terjadi secara langsung maupun tidak langsung ketika konsumen mencari, berbelanja, mengkonsumsi sebuah merek. ${ }^{6}$ Bagaimanapun juga mereka membedah bermacam-macam stimulus merek seperti bentuk, desain, slogan, karakter merek, dan lain sebagainya. ${ }^{7}$ Pengalaman masa lalu dalam memperoleh dan mengkonsumsi merek juga akan membangun ekspektasi konsumen mengenai suatu merek. ${ }^{8}$

Ketika konsumen berinteraksi dengan merek baik secara langsung maupun tidak langsung, sejak mencari informasi mengenai merek sampai akhirnya mengkonsumsi dan pasca konsumsi, maka konsumen akan memiliki pengalaman mengenai merek tersebut, bias jadi pengalaman tersebut positif maupun negatif. Peneliti pemasaran dan konsumen telah menunjukkan ketika konsumen mencari produk, berbelanja dan mengkonsumsi produk serta jasa konsumen akan merasakan pengalaman terhadap suatu merek. Assael mengajukan sebuah model proses informasi yang menjelaskan mengenai informasi yang diterima konsumen itu akan diterima konsumen akan diperhatikan, diorganisir, dan diinterpretasikan sehingga informasi tersebut ditahan didalam memori konsumen, baik memori jangka pendek maupun memori yang sudah difilter menjadi memori jangka panjang dimana memori ini didapat dari persepsi, evaluasi merek, dan pengalaman masa lalu dalam membeli dan mengkonsumsi merek. ${ }^{9}$

Berdasarkan penelitian neuromarketing, stimulus yang diterima individu akan diproses oleh otak sebagai sensasi, dimana kognitif akan diproses didalam otak neomamalia, sedangkan emosi individu akan diproses di dalam sistem limbik yang akan menghasilkan persepsi mengenai suatu objek atau stimulus tersebut. Secara logika, semakin positif stimulus sensorik yang diberikan oleh pemasar kepada konsumen, maka persepsi konsumen terhadap suatu merek tersebut akan positif, baik dari segi kognitif maupun emosinya. Informasi yang diterima konsumen yang sudah diproses melalui kognisi dan emosi akan tertanam dalam memori konsumen yang telah difilter berdasarkan pengalaman masa lalu dalam membeli dan mengkonsumsi merek. Dengan demikian, hipotesis yang diajukan untuk fenomena ini adalah:

H1 : Kognisi pelanggan berpengaruhpositif pada pengalaman merek.

$\mathrm{H} 2 \mathrm{a}$ : Emosi positif pelanggan berpengaruh positif pada pengalaman merek.

$\mathrm{H} 2 \mathrm{~b}$ : Emosi negatif pelanggan berpengaruh negatif pada pengalaman merek.

\footnotetext{
${ }^{6}$ Brakus, J.J., Schmitt, B.H., dan Zarantonello, L. Brand Experience: What is it? How It Measured? Does it Affect Loyalty? Journal of Marketing. 73, 2009, h. 52-68.

7 Sahin, A., Zehir, C., dan Kitapci, H, The Effects of Brand Experiences, Trust and Satisfaction on Building Brand Loyalty: An Empirical Research on Global Brands. Procedia Social and Behavioral Sciences, 24, 2011, h. 1288-1301.

8 Assael, H, Consumer behaviour: A strategic approach. Houghton Mifflin Company, Boston, 2004, h. 33.

9 Ibid.
} 


\section{Skeptisme Pelanggan (Customer Sceticism)}

Istilah skeptisme memiliki beberapa makna, Ford menyatakan bahwa skeptis tidak hanya pada kebenaran literatur klaim periklanan, tapi juga motif pengiklannya; atau kelayakan iklan untuk audien yang spesifik seperti anak-anak, atau produk yang spesifik seperti rokok dan alkohol.10 Skeptisme juga didefinisikan sebagai ketidakpercayaan terhadap klaim yang dinyatakan. ${ }^{11}$ Perlu diketahui juga bahwa konsumen yang skeptis tidak akan menerima klaim iklan. Akan tetapi, menurut Obermiller dan Spangenberg tidak percaya bahwa skeptisme iklan perlu direfleksikan pada kecenderungan yang lebih umum dan tidak untuk mempercayai semua lini komunikasi. Mereka mengkonsepkan bahwa skepstisme pelanggan sebagai kepercayaan pasar. ${ }^{12}$

Sebelum menguji hubungan antara skeptisme pelanggan dengan konstruk yang lain, peneliti mendorong dua pertanyaan mendasar. (1) Apakah nasabah merasa skeptis dengan klaim syariah dari perbankan syariah? (2) Apa yang menyebabkan nasabah skeptis terhadap perbankan syariah? Peneliti menguji antecedent dari skeptisme pelanggan berdasarkan pengalaman konsumsi dari Obermiller dan Spangenberg ; sikap dan perilaku yang diproksikan emosi dan kognisi yang diadopsi dari Lunardo.13 Dalam studi ini peneliti mengajukan hipotesis sebagai berikut:

H3 : Kognisi pelanggan berpengaruh negatif pada skeptisme pelanggan.

H4a : Emosi positif pelanggan berpengaruh negatif pada skeptisme pelanggan.

H4b : Emosi negatif pelanggan berpengaruh positif pada skeptisme pelanggan.

H5 : Pengalaman merek berpengaruh pada skeptisme pelanggan.

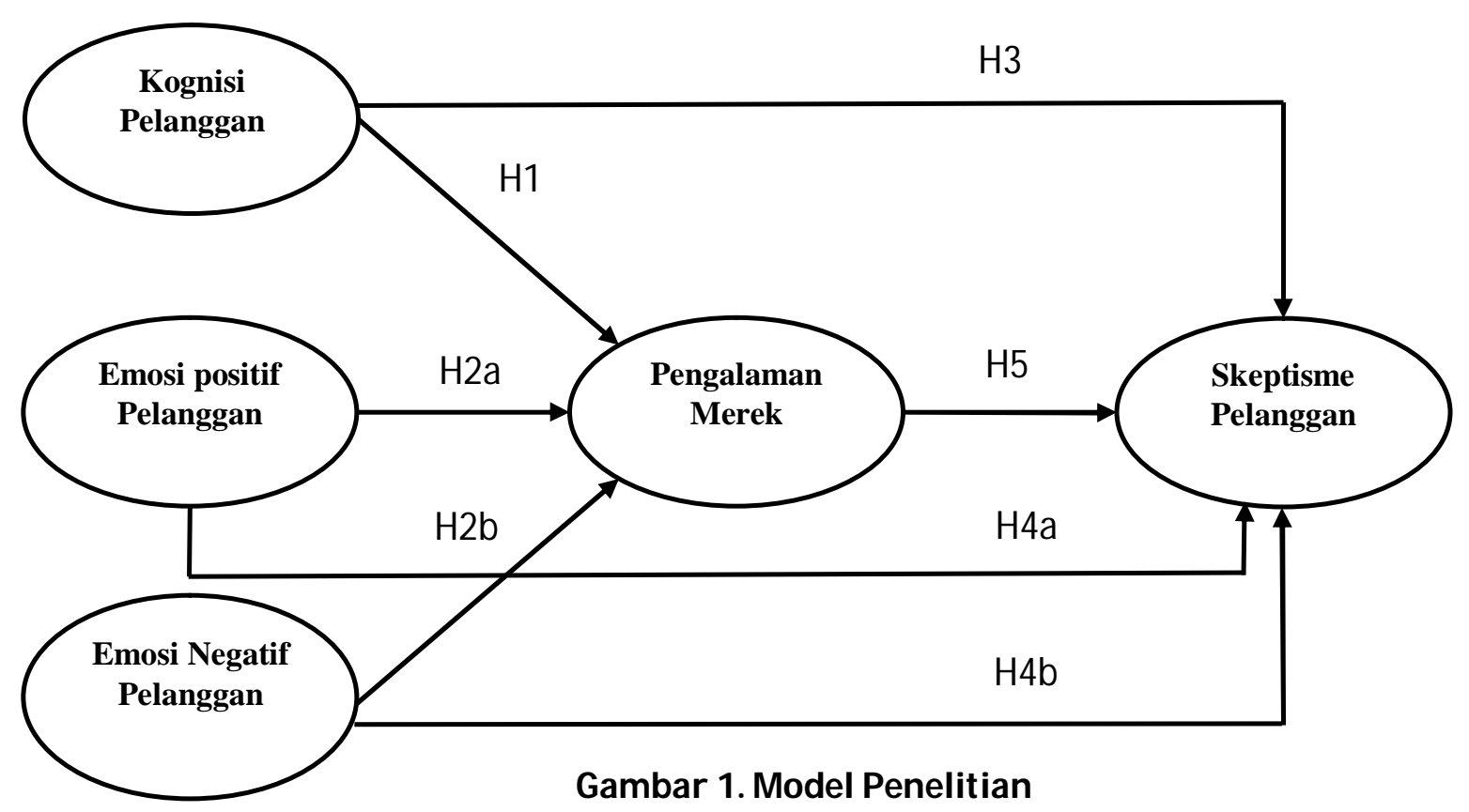

\footnotetext{
${ }^{10}$ Ford, G.T., Smith, D.B. dan Swasy, J.L, Consumer Scepticism of Advertising Claims: Testing Hypotheses from Economics of Information. Journal of Consumer Research. 16, 1990, h. 239-243.

${ }^{11}$ Darley, W.K., dan Smith, R.E., Advertising Claim Objectivity: Antecedents and Effects. Journal of Marketing, 57 (4), 1993, h. 100-113. Lihat juga Pomering, A., dan Johnson, L.W. Advertising Corporate Social Responsibility Initiatives to Communicate Corporate Image: Inhibiting Scepticism to Enhance Persuasion, Corporate Communication: An International Journal, 4 (4), 2009, h. 420-439.

${ }^{12}$ Obermiller, C. dan Spangenberg, E.R., Development of a Scale to Measure Consumer Scepticism toward Advertising. Journal of Consumer Psychology. 7 (2), 1998, h. 159-186.

${ }^{13}$ Lunardo, R., Negative Effects of Ambients Scents on Consumers' Scepticism about Retailer's Motives. Journal of Retailing and Consumer Services. 12, 2012, h. 179-185.
} 


\section{METODE}

\section{Desain Penelitian}

Penelitian ini menggunakan metode kuantitatif untuk mengukur persepsi nasabah bank syariah mengenai klaim syariah yang dikomunikasikan oleh bank syariah. Peneliti lebih fokus pada sikap skeptisme nasabah berdasarkan pengalaman mereka setelah berinteraksi dengan perbankan syariah. Penelitian ini merupakan riset deskriptif kuantitatif yang menjelaskan secara deskriptif mengenai hasil analisis data kuantitatif yang didapatkan dari lapangan. Variabel dalam penelitian ini adalah kognisi, emosi, pengalaman merek dan skeptisme pelanggan. Peneliti melakukan survei untuk mendapatkan data primer yang diambil langsung dari nasabah perbankan syariah, dalam pengumpulan data ini peneliti dibantu oleh enumerator yang sudah dilatih untuk mencari data di lapangan secara online. Setelah data terkumpul, peneliti mengolah data menggunakan uji statistik dan menginterpretasikan hasilnya.14

\section{Populasi dan Sampel}

Populasi didefinisikan oleh Neuman sebagai keseluruhan kelompok yang akan diteliti dalam sebuah penelitian. Populasi dalam penelitian ini adalah seluruh nasabah perbankan syariah sehingga sampel yang digunakan dalam penelitian ini adalah nasabah bank syariah yang tersebar di Indonesia. Diharapkan dengan data yang diperoleh dari nasabah bank syariah yang tersebar di Indonesia, penelitian ini mampu menjelaskan secara nyata mengenai tingkat skeptisme secara general. ${ }^{15}$

Penelitian ini menggunakan metode purposive sampling, Teknik ini dipilih untuk memperoleh responden yang sesuai dengan kriteria-kriteria yang ditetapkan oleh peneliti sesuai dengan apa yang ingin diteliti. Kriteria responden yang digunakan sebagai sampel dalam penelitian ini adalah nasabah bank syariah yang sudah pernah mendapatkan stimulus pemasaran dari bank syariah yang ada di Indonesia. Hal ini karena konsumen akan merasakan pengalaman terhadap merek bank syariah tersebut.

\section{Metode Pengumpulan Data}

Metode pengumpulan data dilakukan dengan survei online menggunakan formulir Google yang langsung dijawab oleh nasabah bank syariah. Kuesioner berisi pernyataan untuk mengukur persepsi nasabah perbankan syariah berdasarkan skala tertentu terkait pengalaman merek dan skeptisme pelanggan. Upaya yang dilakukan peneliti agar instrumen diisi secara lengkap dan objektif oleh responden adalah dengan membuat pernyataan yang mudah dipahami, menggunakan skala yang sama, memberikan tanda harus diisi dan penyebaran kuesionernya dilakukan oleh enumerator yang berasal dari daerah yang berbeda-beda supaya penyebaran data dapat dilakukan dengan baik.

\section{Pengukuran}

\section{Kognisi Pelanggan (CustomerCognition)}

Konsumen membandingkan informasi yang masuk kepada individu dengan struktur pengetahuan yang sudah ada, sehingga akan memproduksi serangkaian pikiran utama mengenai informasi tersebut. Adapun dimensi kognisi pelanggan adalah Belief Strength, Belief Convidence dan Product Curiosity yang diambil dari penelitian Smith dan Swinyard, dimensi ini dikombinasi-

${ }^{14}$ Cooper, D. R., dan Schindler, P. S, Business Research Methods, Eleventh Edition. New York, NY: McGraw Hill, 2011 , h. 55.

15Neuman, W.L., Social Research Methods: Qualitative and Quantitative Approach 6th ed. Pearson International, USA, 2006, h. 33. 
kan dengan dimensi struktur/ respon kognisi dari Toy dengan pernyataan atribut merek yang diukur menggunakan skala Likert lima poin dari satu sampai lima. ${ }^{16}$

\section{Emosi Pelanggan (Customer Emotion)}

Emosi merupakan afektif dari persepsi seseorang pada serangkaian atribut produk atau kinerja layanan, dimana terdapat tiga dimensi dari emosi, yaitu: kesenangan (Pleasure), ketergugahan (Arrousal), dan dominasi (Dominance)yang dikemukakan oleh Mehrabian dan Russel (1974) yang diukur menggunakan skala Likert lima point dari satu sampai lima.

\section{Pengalaman Merek (Brand Experience)}

Dimensi pengukuran pengalaman merek adalah sensorial, afektif, perilaku, dan intelektual yang diukur menggunakan kuesioner yang diambil dari Brakus et al. (2009). Dimensi sensorial ialah dimensi pengalaman yang menunjukkan visual, audio, perasa, peraba, dan pencium yang distimulus oleh merek. Dimensi Afektif ialah dimensi pengalaman yang didalamnya terdapat ikatan emosional. Dimensi intelektual ialah dimensi pengalaman yang menunjukkan kemampuan merek untuk mengikat pemikiran konsumen yang convergent dan divergent. Dimensi perilaku ialah dimensi pengalaman yang menunjukkan kemampuan merek untuk mempengaruhi perilaku konsumen.

\section{Skeptisme Pelanggan (Customer Scepticism)}

Skeptisme pelanggan terhadap klaim syariah diukur menggunakan dimensi pengukuran skeptisme tujuh item skala Likert lima poin yang diambil dari Obermiller dan Spangenberg yang mengukur skeptisme terhadap klaim iklan, kemudian peneliti sesuaikan dengan klaim syariah yang dikomunikasikan oleh perbankan syariah. Skeptisme yang dimaksud disini adalah tendensi umum terhadap ketidakpercayaan klaim syariah yang dirasakan oleh nasabah bank syariah yang ada di Indonesia.

\section{Analisis Data}

Model penelitian ini diuji menggunakan metode regresi berganda dengan menggunakan perangkat lunak SPSS 23. Metode ini digunakan untuk menginterpretasikan uji reliabilitas, uji validitas, uji analisis factor, uji multikolinieritas, uji hipotesis beserta uji model penelitian yang diajukan, serta menilai model stuktural dengan membuatnya menjadi dua model untuk memastikan bahwa ukuran konstruk valid dan reliabel sebelum ditarik kesimpulan. Model struktural dievaluasi menggunakan nilai-nilai $R^{2}$ dan ukuran koefisien jalur struktural.17

\section{HASIL DAN PEMBAHASAN \\ Deskripsi Responden}

Responden dalam penelitian ini adalah 597 orang pengguna bank syariah yang tersebar di Indonesia. Responden mengisi kuesioner yang disebar secara online menggunakan Goggle form yang telah didesain supaya mudah dan efisien dalam pengisiannya. Adapun informasi demografi responden dalam penelitian ini dapat dilihat pada Tabel 1. dibawah yang menunjukkan bahwa pengguna bank syariah tersebar di berbagai kalangan masyarakat, baik dari sisi jenis kelamin (mayoritas perempuan dengan jumlah 60,1\%), usia (mayortias 21-30 tahun sebanyak 74\%),

\footnotetext{
${ }^{16}$ Toy, D.R, Monitoring Communication Effects: A Cognitive Structure/ Cognitive Response Approach. Journal of Consumer Research. 9 (1), 1982, h. 66-76.

${ }^{17}$ Hartmann, F., Naranjo-Gil, D., dan Perego, P., The Effect of Leadership Styles and Use of Performance Measures on Managerial Work-Related Attitude. European Accounting Review, 19 (2), 2010, h. 275-310.
} 
pendidikan (mayoritas D4/ S1 dengan jumlah 72\%), pekerjaan (mayoritas pelajar/mahasiswa sebanyak 75,5\%), pendapatan (mayoritas responden memiliki pendapatan $\leq$ Rp.1.400.000 yaitu 75,5\%), bank syariah (paling banyak adalah nasabah BSM dengan 36,2\%) dan lama menjadi nasabah (mayoritas diatas 2 tahun sebanyak 31\%).

Tabel 1. Informasi Demografi Responden

\begin{tabular}{|c|c|c|c|}
\hline Variabel & Deskripsi & Frekuensi & Persentase (\%) \\
\hline Jenis Kelamin & $\begin{array}{l}\text { Laki-laki } \\
\text { Perempuan }\end{array}$ & $\begin{array}{l}238 \\
359\end{array}$ & $\begin{array}{l}39,9 \\
60,1\end{array}$ \\
\hline Usia & $\begin{array}{l}\leq 20 \text { tahun } \\
21-30 \text { tahun } \\
31-40 \text { tahun } \\
41-50 \text { tahun } \\
\geq 51 \text { tahun }\end{array}$ & $\begin{array}{c}37 \\
442 \\
82 \\
19 \\
17\end{array}$ & $\begin{array}{c}6,2 \\
74 \\
13,7 \\
3,2 \\
2,8\end{array}$ \\
\hline Pendidikan & $\begin{array}{l}\text { SMA/ SMK/ Sederajat } \\
\text { D1/ D3 } \\
\text { D4/ S1 } \\
\text { S2/ S3 } \\
\text { Lainnya }\end{array}$ & $\begin{array}{c}128 \\
2 \\
430 \\
30 \\
7\end{array}$ & $\begin{array}{c}21,4 \\
0,3 \\
72 \\
5 \\
1,2\end{array}$ \\
\hline Pekerjaan & $\begin{array}{l}\text { Mahasiswa/ Pelajar } \\
\text { PNS/ BUMN } \\
\text { Karyawan Swasta } \\
\text { Wiraswasta/ Entrepreneur } \\
\text { Lainnya }\end{array}$ & $\begin{array}{c}451 \\
29 \\
71 \\
33 \\
13\end{array}$ & $\begin{array}{c}75,5 \\
4,9 \\
11,9 \\
5,5 \\
2,2\end{array}$ \\
\hline Pendapatan & $\begin{array}{l}\leq \text { Rp.1.400.000 } \\
\text { Rp.1.400.001 - Rp.2.700.000 } \\
\text { Rp.2.700.001 - Rp.4.000.000 } \\
\geq \text { Rp.4.000.001 }\end{array}$ & $\begin{array}{r}428 \\
87 \\
39 \\
43\end{array}$ & $\begin{array}{r}71,7 \\
14,6 \\
6,5 \\
7,2\end{array}$ \\
\hline Nasabah Bank Syariah & $\begin{array}{l}\text { BSM } \\
\text { BNIS } \\
\text { BRIS } \\
\text { Muamalat } \\
\text { BTN Syariah } \\
\text { BCA Syariah } \\
\text { Bukopin Syariah } \\
\text { Mega Syariah } \\
\text { BTPN Syariah } \\
\text { CIMB Niaga Syariah } \\
\text { Permata Syariah } \\
\text { BPRS Syariah } \\
\text { BPD Syariah }\end{array}$ & $\begin{array}{r}216 \\
58 \\
137 \\
135 \\
9 \\
8 \\
8 \\
4 \\
2 \\
9 \\
3 \\
4 \\
4\end{array}$ & $\begin{array}{r}36,2 \\
9,7 \\
22,9 \\
22,6 \\
1,5 \\
1,3 \\
1,3 \\
0,7 \\
0,3 \\
1,5 \\
0,5 \\
0,7 \\
0,7\end{array}$ \\
\hline Lama Menjadi Nasabah & $\begin{array}{l}\leq 3 \text { bulan } \\
3 \text { bulan }-6 \text { bulan } \\
6 \text { bulan }-1 \text { tahun } \\
1 \text { tahun }-2 \text { tahun } \\
\geq 2 \text { tahun }\end{array}$ & $\begin{array}{r}70 \\
116 \\
110 \\
116 \\
185\end{array}$ & $\begin{array}{r}11,7 \\
19,4 \\
18,4 \\
19,4 \\
31\end{array}$ \\
\hline Jumlah Sampel, N =597 & & & \\
\hline
\end{tabular}




\section{Analisis Faktor dan Reliabilitas}

Sebelum pengujian hipotesis, perlu dilakukan uji validitas dan reliabilitas instrumen agar data yang diperoleh reliabel dan valid.18 Analisis factor dan hasil pengukuran dalam penelitian ini dapat dilihat pada Tabel 2 berikut.

Tabel 4.2 Analisis Faktor dan Hasil Item Pengukuran

\begin{tabular}{|c|c|c|c|c|c|c|c|}
\hline \multirow[t]{2}{*}{ Factor } & \multirow[t]{2}{*}{ Mean } & \multirow[t]{2}{*}{ S.D } & \multicolumn{5}{|c|}{ Factor Loading } \\
\hline & & & 1 & 2 & 3 & 4 & 5 \\
\hline $\begin{array}{l}\text { Kognisi Pelanggan (KG) } \\
\text { Cronbach } \alpha=.912\end{array}$ & 3.73 & .65 & & $\begin{array}{l}.609 \\
.725 \\
.693 \\
.722 \\
.797 \\
.646 \\
.607\end{array}$ & & & \\
\hline $\begin{array}{l}\text { Emosi Positif Pelanggan } \\
\text { (EMA) Cronbach } \alpha=.893 \\
\text { Emosi Negatif Pelanggan } \\
(\text { EMB) }\end{array}$ & 3.78 & .77 & & & & $\begin{array}{l}.753 \\
.741 \\
.761\end{array}$ & \\
\hline Cronbach $\alpha=.769$ & 2.73 & .78 & & & & & $\begin{array}{l}.838 \\
.707 \\
.749\end{array}$ \\
\hline $\begin{array}{l}\text { Pengalaman Merek (PM) } \\
\text { Cronbach } \alpha=.872\end{array}$ & 3.53 & .64 & & & $\begin{array}{l}.547 \\
.592 \\
.700 \\
.622 \\
.619 \\
.649 \\
.572\end{array}$ & & \\
\hline $\begin{array}{l}\text { Skeptisme Pelanggan (SK) } \\
\text { Cronbach } \alpha=.919\end{array}$ & 2.40 & .62 & $\begin{array}{l}.657 \\
.719 \\
.762 \\
.750 \\
.788 \\
.760 \\
.699\end{array}$ & & & & \\
\hline KMOTest & .957 & & & & & & \\
\hline Barlett's Test & 10465. & & & & & & \\
\hline Sig. & .000 & & & & & & \\
\hline
\end{tabular}

Tabel 2 di atas menunjukkan bahwa variabel dalam penelitian ini dinilai reliabel dengan nilai Cronbach alpha untuk variabel KG adalah 0,912, EMA 0,893, EMB 0,769, PM 0,872 dan SK 0,919 . Selain itu, uji validitas menunjukkan nilai yang baik dengan nilai KMO 0,957 dan nilai Barlett's 10465,368 dengan tingkat signifikansi 0,000. Selanjutnya, instrumen setiap variabel sudah terkonsentrasi pada faktornya masing-masing yang telah diuji menggunakan conformatory factor analysis (CFA). Peneliti juga melakukan principal component analysis menggunakan varimax rotation untuk mencari data terbaik.

18Cooper, D. R., dan Schindler, P. S, Business Research Methods, Eleventh Edition. New York, NY: McGraw Hill, 2011, 98. 


\section{Analisis Korelasi}

Analisis korelasi diperlakukan sebelum melakukan uji hipotesis yaitu dengan menghitung mean dan standart deviation untuk setiap variabel serta membuat matriks korelasi yang digunakan untuk menguji hipotesis. Hasil analisis korelasi ditunjukkan pada Tabel 3 berikut.

Tabel 3. Mean, Standart Deviation, Correlation Analysis

\begin{tabular}{|c|c|c|c|c|c|c|c|}
\hline Variabel & Mean & S.D & EMA & EMB & KG & PM & SK \\
\hline EMA & 3.78 & .77 & 1 & $.055^{*}$ & $.693^{* *}$ & $.625^{* *}$ & $-.558^{* *}$ \\
\hline EMB & 2.73 & .78 & & 1 & $.084^{*}$ & $.213^{* *}$ & $.087^{*}$ \\
\hline KG & 3.73 & .65 & & & 1 & $.751^{* *}$ & $-.685^{* *}$ \\
\hline PM & 3.53 & .64 & & & & 1 & $-.698^{* *}$ \\
\hline SK & 2.40 & .62 & & & & & 1 \\
\hline
\end{tabular}

*Korelasi signifikan pada level 0,05, ${ }^{* *}$ korelasi signifikan pada level 0,01 (2-tailed).

Berdasarkan Tabel 3 di atas, terlihat bahwa untuk variabel yang arahnya positif bernilai mean lebih dari 3 sedangkan untuk variabel yang arahnya negatif bernilai di bawah 3 dari 5 point skala Likert. Variabel EMA paling tinggi dengan nilai mean $=3.78$, dilanjutkan variabel KG dengan nilai mean $=3.73$, variabel PM dengan nilai mean $=3.53$. Hal ini bermakna bahwa responden setuju bahwa mereka menggunakan kognisi dan emosi positif dalam menggunakan bank syariah, serta merasakan pengalaman terhadap merek bank syariah tersebut. Untuk variabel yang berarah negatif memiliki nilai mean $=2.73$ untuk variabel $\mathrm{EMB}$ dan nilai mean $=2.40$ untuk variabel SK. Hal ini bermakna bahwa responden tidak setuju bahwa mereka percaya terhadap klaim syariah dari bank syariah (kuesioner di reverse menjadi pernyataan positif). Setelah melakukan analisis pada Tabel 4.3, peneliti melihat adanya hubungan yang signifikan antara variabel KG, EMA, EMB, PM, dan SK yang berkorelasi pada level $\mathrm{P} \varangle 0,01$ dan $\mathrm{P} \varangle 0,05$.

\section{Analisis Regresi (Uji Hipotesis)}

Analisis regresi berganda dilakukan dengan menggunakan alat statistic SPSS. Output regresi terdiri dari dua model, dimana hasil uji regresi berganda ini dapat dilihat pada Tabel 4 berikut.

Tabel 4. Analisis Regresi Model I dan Model II

\begin{tabular}{|l|l|c|c|c|c|c|c|}
\hline \multicolumn{2}{|c|}{$\begin{array}{c}\text { Model I } \\
\text { Pengalaman Merek }\end{array}$} & \multicolumn{2}{c|}{$\begin{array}{c}\text { Model II } \\
\text { Skeptisme }\end{array}$} & \multicolumn{3}{c|}{ Collinearity Statistic } \\
\hline \multicolumn{2}{|c|}{ Beta } & Sig. & Beta & Sig. & VIF & Tollerance & SE \\
\hline Kognisi H1, H3 & .598 & .000 & -.323 & .000 & 1.932 & .518 & .595 \\
\hline Emosi H2a, H2b, & .202 & .000 & -.077 & .000 & 1.924 & .520 & .169 \\
H4a, H4b & -.151 & .000 & .032 & .000 & 1.007 & .993 & .125 \\
\hline $\begin{array}{l}\text { Pengalaman } \\
\text { Merek H5 }\end{array}$ & - & - & -.414 & .000 & 2.548 & .393 & .042 \\
\hline R2 & .779 & & & & & & \\
\hline F & 305.998 & .551 & 181.267 \\
\hline Sig. & .000 & .000 \\
\hline
\end{tabular}

Tabel 4 di atas menjelaskan informasi bahwa Model I menunjukan variabel KG, EMA, dan EMB sebagai variabel independen serta variabel PM sebagai variabel dependen. Analisis regresi pada Model I ini secara statistik memiliki dampak positif pada variabel KG dan EMA yang 
menunjukkan pengaruh positif dan variabel EMB memiliki pengaruh negatif dengan nilai $(\mathrm{F}=$ 305,998; R2 =0,779; Sig. = 0,000) dimana F hitung lebih besar dari F tabel, maka Ho ditolak dan Ha diterima. Analisis regresi ini mengindikasikan bahwa KG dan EMA berpengaruh positif pada $\mathrm{PM}(\mathrm{P}<0,01 ; \beta=0,751)$ dan $(\mathrm{P}<0,01 ; \beta=0,625)$. Sedangkan EMB berpengaruh negatif pada $\mathrm{PM}$ $(\mathrm{P}<0,01 ; \beta=0,213)$. Hal ini menunjukkan bahwa $\mathrm{H1}, \mathrm{H} 2 \mathrm{a}$, dan $\mathrm{H} 2 \mathrm{~b}$ dapat diterima.

Model II dalam penelitian ini menunjukkan variabel KG, EMA, EMB, dan KG sebagai variabel independen serta variabel SK sebagai variabel dependen. Analisis regresi pada Model II ini variabel KG, EMA dan PM berpengaruh negatif pada variabel SK dengan nilai $(F=181,267$; R2 = 0,551; Sig. = 0,000) dimana F hitung lebih besar dari F tabel, maka Ho ditolak dan Ha diterima. Hal ini menunjukkan bahwa variabel KG, EMA, dan PM menunjukkan pengaruh negatif pada variabel SK pada level $(\mathrm{P}<0,01 ; \beta=-0,685)$ untuk $K G,(\mathrm{P}<0,01 ; \beta=-0,558)$ untuk EMA, dan $(\mathrm{P}<0,01 ; \beta=-, 698)$. Sedangkan variabel EMB berpengaruh positif pada variabel SK dengan nilai $(\mathrm{P}<0,05 ; \beta=0,087)$. Berdasarkan pengujian tersebut maka H3, H4a, H4b, dan H5 dapat diterima.

Berdasarkan uji multikolinieritas menunjukkan bahwa nilai VIF kurang dari 10 dan nilai tolerance lebih dari 0,01 serta nilai standart error kurang dari 1. Hal tersebut menunjukkan bahwa tidak terdapat masalah multikolinieritas, sehingga dapat dikatakan bahwa pengujian statistic tersebut telah reliabel, dapat dipercaya, dan robust. Hasil dari regresi juga menunjukkan bahwa semua hipotesis terdukung secara signifikan.

\section{Diskusi}

Menurut Darsono tantangan perbankan Syariah begitu beragam pada beberapa aspek. Pertama, paradigma berpikir masyarakat sebagai pengguna, pelaku, maupun regulator industri keuangan cenderung konvensional. Kedua, industri perbankan syariah masih dikembangkan secara parsial baik pada tingkat kebijakan dan regulasi, kelembagaan dan operasional serta SDM dan sistem Pendidikan. Ketiga, kurangnya kerjasama antara bank syariah dengan Lembaga keuangan mikrosyariah. Keempat, sinergi yang juga belum terwujud pada tingkat sektoral, misalnya sektor keuangan syariah yang bersifat komersial (perbankan dan non perbankan) dengan sektor keuangan sosial syariah (Lembaga zakat, wakaf, dan infak-sedekah). Kelima, belum ada kebijakan dari pemerintah atau kementerian yang secara tegas memperlihatkan keberpihakan dalam mengembangkan industri keuangan syariah meski telah terbukti memiliki ketahanan dalam menghadapi krisis. ${ }^{19}$

Dalam studi ini, peneliti menguji paradigma berpikir dan sikap nasabah perbankan syariah menggunakan perspektif theory of reason action (TRA) dari Ajzen dan Fishbein untuk melihat skeptisme nasabah perbankan syariah yang ada di Indonesia. Dimana persepsi ini dilihat berdasarakan faktor-faktor yang mempengaruhi skeptisme pelanggan, yaitu kognisi pelanggan, emosi pelanggan, dan pengalaman merek.

Hasil pengujian statistik menunjukkan bahwa kognisi berpengaruh positif pada pengalaman merek, artinya responden merasakan stimuli yang diberikan perbankan syariah, menghubungkan stimuli dengan kebutuhan, mengevaluasi merek alternatif dan menafsirkan apakah produk tersebut sesuai dengan ekspektasi. ${ }^{20} \mathrm{Hal}$ ini juga sesuai dengan penelitian Fiore dan Kim bahwa dalam model CAB (cognitive-affect-behavior) merepresentasikan tentang aktivitas mental yang mempengaruhi perilaku konsumen, dimana aktifitas kognisi pelanggan akan tersimpan dalam memori dan menjadi sebuah pengalaman merek. Peneliti menemukan bahwakognisi pelanggan berpengaruh negatif pada skeptisme pelanggan, hal ini karena tingkat skeptisme akan

\footnotetext{
19Darsono, Astiyah, dkk, Perbankan Syariah di Indonesia: Kelembagaan dan Kebijakan Serta Tantangan ke Depan. Rajawali Pers. Jakarta, 2017, h. 89.

20Assael, H, Consumer behaviour: A strategic approach. Houghton Mifflin Company, Bosto, 2004, h. 68.
} 
menurun ketika pelanggan semakin memahami informasi-informasi yang diterima dan mengevaluasi informasi yang sesuai dengan kebutuhan pelanggan dan kesesuaian dengan ekspektasi mereka.

Emosi pelanggan terbagi menjadi dua, yaitu emosi positif dan emosi negatif dimana emosi positif pelanggan berdampak positif pada pengalaman merek, sedangkan emosi negatif pelanggan berdampak negatif pada pengalaman merek. Hal ini sesuai dengan hipotesis yang diajukan peneliti, dimana peneliti mengikuti saran dari Brakus untuk memisahkan emosi pelanggan (afektif) menjadi positif dan negatif, karena kedua hal ini bisa menyebabkan respon yang berbeda pada pengalaman merek konsumen. ${ }^{21} \mathrm{Hal}$ ini sesuai dengan penelitian Jang dan Namkung yang menguji emosi positif dan emosi negatif secara terpisah pada niat pelanggan untuk berperilaku. ${ }^{22}$ Emosi negatif pelanggan juga berpengaruh positif pada skeptisme pelanggan, hal ini bermakna ketika emosi negatif meningkat maka skeptisme pelanggan juga akan meningkat, peneliti menduga hal ini karena emosi negatif akan memberikan dampak yang kuat pada sikap negative, yaitu skeptisme (su'udzon) kepada merek. Obermiller dan Spangenberg menyatakan bahwa mungkin konsumen tidak selalu percaya terhadap klaim yang diberikan oleh perusahaan, serta mungkin faktor situasional bisa menjadi memoderasi respon skeptis yang ekstrim. ${ }^{23}$

Penelitian ini juga menemukan bahwa pengalaman merek berpengaruh pada skeptisme pelanggan, dimana hasil statistik menunjukkan bahwa pengalaman merek berpengaruh negatif pada skeptisme pelanggan sesuai dengan yang dihipotesiskan. Peneliti mengasumsikan bahwa pengalaman di sini adalah pengalaman positif yang tercermin dari item-item indikator penelitian. Hal ini bermakna bahwa semakin positif pengalaman nasabah bank syariah, maka tingkat skeptisme akan semakin menurun dan begitupun sebaliknya. Hal ini sesuai dengan penelitian Obermiller dan Spangenberg tentang pengalaman konsumsi terhadap tingkat skeptis konsumen pada iklan dengan pendekatan kepercayaan pasar terhadap bermacam-macamnya individu yang digunakan untuk menghubungkan dengan persuasi secara umum. ${ }^{24}$

\section{PENUTUP}

Penelitian ini bertujuan menguji faktor-faktor yang mempengaruhi tingkat skeptisme nasabah bank syariah yang ada di Indonesia, dimana peneliti mencoba meriset paradigma berpikir dan sikap nasabah perbankan syariah menggunakan perspektif theory of reason action (TRA) dari Ajzen dan Fishbein (1980) untuk melihat tingkat skeptisme nasabah perbankan syariah yang ada di Indonesia. Dimana persepsi ini dilihat berdasarakan faktor-faktor yang mempengaruhi skeptisme pelanggan, yaitu kognisi pelanggan, emosi pelanggan, dan pengalaman merek.

Semua hipotesis yang diajukan dalam penelitian ini terdukung. Hasil ini menunjukkan bahwa dalam konteks perbankan syariah yang ada di Indonesia, peneliti menemukan bahwa tingkatskeptismeakan menurun ketika pelanggan semakin memahami informasi-informasi yang diterima dan mengevaluasi informasi yang sesuai dengan kebutuhan pelanggan dan kesesuaian dengan ekspektasi mereka. Ketika emosi negatif meningkat maka skeptisme pelanggan juga akan meningkat, peneliti menduga hal ini karena emosi negatif akan memberikan dampak yang kuat pada sikap negative, yaitu skeptisme (su'udzon) kepada perbankan syariah. Peneliti juga menemukan bahwa semakin positif pengalaman nasabah terhadap bank syariah, maka tingkat skeptisme akan semakin menurun dan begitupun sebaliknya. Hal ini didukung penelitian

\footnotetext{
${ }^{21}$ Brakus, J.J., Schmitt, B.H., dan Zarantonello, L., Brand Experience: What is It? How it Measured? Does It Affect Loyalty? Journal of Marketing. 73, 2009, h. 52-68.

22 Jang, S.C., dan Namkung, Y, Perceived Quality, Emotions and Behavioural Intentions: Aplication of an Extended Mehrabian-Russell Model to Restaurants. Journal of Business Research. 62, 2009, h. 451-460.

${ }^{23}$ Obermiller, C. dan Spangenberg, E.R., Development of a Scale to Measure Consumer Scepticism toward Advertising. Journal of Consumer Psychology. 7 (2), 1998, h. 159-186. 24Ibid.
} 
Obermiller dan Spangenberg (1998) tentang pengalaman konsumsi terhadap tingkat skeptisme konsumen pada klaim suatu iklan dengan pendekatan kepercayaan pasar.

\section{Implikasi}

Peneliti mencoba untuk memberikan kontribusi penting, baik secara praktis maupun teoretis, dimana secara praktis penelitian ini memberikan informasi penting kepada perbankan syariah bahwa nasabah masih memiliki sikap skeptis terhadap klaim syariah dari perbankan syariah, meskipun tingkat skeptis ini tidak tinggi tapi perlu segera ditangani oleh para manajer di bank syariah karena skeptisme ini juga ditemukan pada nasabah yang sudah loyal dan lebih dari dua tahun menggunakan bank syariah. Peneliti menekankan bahwa nasabah yang sudah menggunakan bank syariah saja masih ada yang skeptis terhadap syariahnya bank syariah, bagaimana dengan masyarakat umum yang belum menggunakan bank syariah? Mungkin hal ini perlu diperhatikan manajer bank syariah untuk lebih meningkatkan literasi dan edukasi pasar supaya market share bank syariah bias semakin meningkat lagi. Kemudian, secara teoritis penelitian ini memberikan kontribusi literatur dengan melakukan pengujian skeptisme pelanggan perbankan syariah yang mana masih menjadi celah penelitian dalam riset pemasaran dan perilaku konsumen pada umumnya dan riset perbankan syariah secara khusus.

\section{Batasan dan Saran Penelitian}

Berikut ini adalah uraian beberapa keterbatasan yang dimiliki oleh penelitian ini dan beberapa saran bagi penelitian dimasa mendatang, seperti berikut.

1. Penelitian ini dalam menguji variabel emosi memisahkan antara emosi positif dan emosi negatif, akan tetapi untuk pengalaman merek peneliti hanya mengasumsikan pengalaman positif saja. Sarannya adalah untuk penelitian dimasa mendatang, peneliti perlu memisahkan pengalaman positif dan negatif serta memasukkan variabel situasional sebagai moderasi supaya lebih jelas bagaimana hubungan antara emosi, pengalaman merek dan sikap skepticme nasabah perbankan syariah.

2. Untuk variabel pengalaman merek, sampai saat ini masih menggunakan instrument dari Brakus et al. (2009). Padahal kelemahan item instrumen ini ketika diterjemahkan dalam Bahasa Indonesia akan mengalami kesulitan untuk dipahami dan konteksnya kalau digunakan dalam perbankan syariah perlu dilakukan penyesuaian. Untuk penelitian dimasa yang akan datang, peneliti perlu melakukan riset yang fokus membuat instrumen penelitian untuk variabel pengalaman merek dalam konteks industri jasa keuangan atau perbankan.

\section{DAFTAR PUSTAKA}

Assael, H. 2004. Consumer behaviour: A strategic approach. Houghton Mifflin Company, Boston.

Bank Indonesia. 2014. Kebijakan Makroprudensial dan Stabilitas Sistem Keuangan, Penjelasan Kebijakan Makroprudensial BI.

Brakus, JJ., Schmitt, B.H., dan Zarantonello, L. 2009. Brand Experience: What is it? How it measured? Does It Affect Loyalty? Journal of Marketing. 73, pp. 52-68.

Calfee, J. E., dan Ringwold, D.J. 1994. The 70\% Majority: Enduring Consumer Belief About Advertising. Journal of Public Policy \& Marketing. 13 (2).

Chapra, M.U. 2006. The nature of riba in Islam. The Journal of Islamic Economics and Finance, 2(1), pp. 7-25. 
Cooper, D. R., dan Schindler, P. S. 2011. Business Research Methods, Eleventh Edition. New York, NY: McGraw Hill.

Darley, W.K., dan Smith, R.E., 1993. Advertising Claim Objectivity: Antecedents and Effects. Journal of Marketing, 57 (4), pp. 100-113.

Darsono, dkk. 2017. Perbankan Syariah di Indonesia: Kelembagaan dan Kebijakan Serta Tantangan ke Depan. Rajawali Pers. Jakarta.

Fiore, A.M. dan Kim, J. 2007. An Integrative Framework Capturing Experiential and Utilitarian Shopping Experience, International Journal of Retail and Distribution Management. 35 (6), 421-442.

Ford, G.T., Smith, D.B. dan Swasy, J.L. 1990. Consumer Scepticism of Advertising Claims: Testing Hypotheses from Economics of Information. Journal of Consumer Research. 16, pp. 239243.

Hartmann, F., Naranjo-Gil, D., dan Perego, P., 2010. The Effect of Leadership Styles and Use of Performance Measures on Managerial Work-Related Attitude. European Accounting Review, 19 (2), 275-310.

Jang, S.C., dan Namkung, Y. 2009. Perceived Quality, Emotions and Behavioural Intentions: Aplication of an Extended Mehrabian-Russell Model to Restaurants. Journal of Business Research. 62, pp. 451-460.

Jarvenpaa, S.L., Tractinsky, N. dan Vitale, M. 2000. Consumer Trust in an Internet Store. Informaation Technology and Management, 1(1), pp.45-71.

Kalafatis, S.P., dan Pollard, M. 1999. Green Marketing and Ajzen's Theory of Planned Behaviour: a Cross-Market Examination.Journal of Consumer Marketing, 35(3), pp. 24-35.

Kotler, P. dan Keller, K.L. 2011. Marketing Management 14th ed. Pearson Education. New Jersey.

Lindstrom, M., 2005. Broad sensory branding. Journal of Product and Brand Management, 14 (2), pp. 84-87.

Lunardo, R. 2012. Negative Effects of Ambients Scents on Consumers' Scepticism about Retailer's Motives. Journal of Retailing and Consumer Services. 12, pp. 179-185.

MacLean, P.D. 1990. The Triune Brain in Evolution: Role in Paleocerebral Functions. Springer Sciences and Business Media.

Mehrabian, A., dan Russel, JA. 1974. An Approach to Environmental Psychology. The MIT Press. Cambridge.

Neuman, W.L. 2006. Social Research Methods: Qualitative and Quantitative Approach 6th ed. Pearson International, USA.

Obermiller, C. dan Spangenberg, E.R., 1998. Development of a Scale to Measure Consumer Scepticism toward Advertising. Journal of Consumer Psychology. 7 (2), pp. 159-186 
Otoritas Jasa Keuangan. 2017. Booklet Perbankan Indonesia 2017. Departemen Perizinan dan Informasi Perbankan Otoritas Jasa Keuangan.

Pomering, A., dan Johnson, L.W. 2009. Advertising Corporate Social Responsibility Initiatives to Communicate Corporate Image: Inhibiting Scepticism to Enhance Persuasion, Corporate Communication: An International Journal, 4 (4), pp. 420-439.

Sahin, A., Zehir, C., dan Kitapci, H. 2011. The Effects of Brand Experiences, Trust and Satisfaction on Building Brand Loyalty: An Empirical Research on Global Brands. Procedia Social and Behavioral Sciences, 24, pp 1288-1301.

Toy, D.R. 1982. Monitoring Communication Effects: A Cognitive Structure/ Cognitive Response Approach. Journal of Consumer Research. 9 (1), pp. 66-76.

www.bankmuamalat.co.id.Akses pada tanggal 02 Oktober 2017.

www.bi.go.id. Diakses pada tanggal 02 Oktober 2017. 